\title{
Loyalty Programs for the Passenger Transportation Industry: A Study of Zimbabwean Companies
}

\author{
Farium Kautsiro ${ }^{1}$ \& Olawumi D. Awolusi² \\ ${ }^{1}$ University of Roehampton, London, UK \\ ${ }^{2}$ Kampala International University, Kampala, Uganda \\ olutayo.olatunji@roehampton-online.ac.uk, awolusi.olawumi@kiu.ac.ug
}

\begin{abstract}
The paper examined firstly whether companies in the passenger transportation industry have utilised loyalty programs and then ascertained how much value the companies have drawn from them in enhancing market share, operational efficiency and financial benefit. Specifically, the study assessed the influence of loyalty program on customer relationship management, operational efficiency and profitability. The research was undertaken on ten companies who have implemented some form of loyalty programs through applied research's in-depth interviews with the top executives. The qualitative methodology was utilised to simplify and manage the collection of data without affecting the environment and context. Data collected were further analysed via Chi-square statistics and the three hypotheses were tested at $5 \%$ level of significance. The results indicate that companies have begun to utilise loyalty programs in their operations, though not entirely sweating the programs to attain the best possible value from them. Most importantly, the study concluded on the positive significant relationship between loyalty program and customer relationship management, operational efficiency and profitability in the Zimbabwe loyalty program. Both filled a few highlighted gaps in the literature. Research for the road passenger transportation sub-sector offers useful theoretical and managerial implications as few studies have been conducted for the airline industry, which has successfully implemented loyalty programs through frequent flier schemes. It is recommended that companies should ascertain passenger behaviour through passenger registration, thereby enhancing the sustainability of the relationship. This study provides theoretical support for the importance of loyalty programs as passenger relationship management tools if appropriately applied and implemented. Loyalty programs offer companies across industrial sectors with useful benefits such as brand loyalty, business efficiency due to enhanced planning and profitability due to increase in patronage from passengers who are less sensitive to the marketing efforts of competing brands. This knowledge should, therefore, enable transporters to ascertain the value of adopting and using loyalty programs appropriately thereby enhancing their competitive advantage in a fast-paced world economy.
\end{abstract}

Keywords: Loyalty program, operational efficiency, profitability, Transportation Industry, Zimbabwe.

\section{Introduction}

Economic concepts in the modern era expect businesses to develop more scientific approaches to attaining positive organisational performance by using innovation. Customer loyalty programs world-over allow companies to retain patronage by encouraging repeat purchases (Jang \& Mattila, 2005). Loyalty programs as a tool for relationship management are structured marketing processes meant introduce rewards as a system to instil buying behaviour that is loyal thereby enhancing the opportunities for businesses to retain customers (Sharp \& Sharp, 1997). As competition for customers is not peculiar to the passenger transportation sector or Zimbabwe in general, it is imperative to appreciate that the same fate befalls all other companies and industrial sectors world over. Critical to this realisation is that passenger transportation companies in the country have had to find over the past ten years the value of encouraging repeat business as it is cheaper to keep an existing passenger (Jang \& Mattila, 2005). Before the adoption of a multi-currency system for the country in January 2009.

There was virtually no incentive on offer for passengers in the industry and loyalty was more attained due to employee-passenger relations or general brand association through subjective value (Temporal, 2000). However, after January 2009, the adoption of the multi-currency regime with the United States Dollar and the South African Rand being the most favoured currencies. In 2010, the Government of Zimbabwe promulgated the Indigenisation and Empowerment Act which identified the passenger transportation industry a sector reserved for local indigenous people (Basera, 2014). The enactment of the Act witnessed an influx of new entrants into the road passenger transportation industry with the majority of players fitting into the 
operational matrix that was in existence over the years. Resultantly, increasing the number of alternative modes that has resulted in a higher number of options for the passengers and forcing firms to undercut fares. As a way to remain competitive but ultimately reducing switching costs for passengers (Thompson \& Chmura, 2015), on the positive, the challenges introduced by the reservation of the industry saw innovative companies in the sector identifying that the need to continuously acquire passengers creates an increase in marketing costs thereby reducing profitability. Leading them to introduce essential rewards and incentives, the companies have been able to retain passengers (Vilkaite-Vaitone \& Papsiene, 2016) and create what has essentially become a distinct market segment. Increasing passengers switching costs will remain difficult for bus companies due to the high supply of alternative modes of transportation, players have had to introduce modern coaches and buses with varying exclusive services and products to enhance safety and comfort.

Problem Statement: The research is meant to determine the extent to which the use of loyalty programs by a selected group of passenger transportation companies in Zimbabwe have influenced their ability to enhance brand management, customer-company relations and loyalty to the brand. Creating a sustainable customercompany identity has been a significant challenge in the Zimbabwean passenger transportation sector due to an abundance of alternative modes of transport both formal and informal. Managing passenger relationship marketing has thus become almost impossible due to the unsustainable availability of alternatives (Basera, 2014). Though, some industry leaders are coming up with different innovations to improve brand management as well as patronage, passenger loyalty programs that in main offer discounts and incentives have gradually found their way into the Zimbabwean industry leading to their adoption by companies. The qualitative study to be undertaken will focus firstly on ascertain the influence that current loyalty programs have had for the companies in improving relationship marketing. Secondly, the study will verify the value the programs bring towards improving the overall company performance. The data collected during this study will provide the Zimbabwean passenger transportation industry leaders with ammunition to enhance the adoption of loyalty programs as well as come up with the necessary designs and implementation processes for the programs to attain maximum value.

For the industry players though, there is currently more than sufficient research on the necessity of customer loyalty programs and the attached importance they bring to business enterprises world over (Beck et al., 2015; Magatef \& Tomalieh, 2015; Sharp \& Sharp, 1997; Jang \& Mattila, 2005; Vilkaite-Vaitone \& Papsiene, 2016). Using loyalty programs to manage customer-company relations has been a master-stroke in enhancing the former's retention thereby reducing marketing costs which is something the passenger transportation sector in the country will be well advised to embrace (Kang et al., 2015). In Zimbabwe, loyalty programs have been predominantly utilised in the retail sector and have not been applied aggressively in the passenger transportation sector. It is paramount for a study to be conducted that focuses on highlighting the success and need for loyalty programs to be embraced in the passenger transportation sector of the country thereby assessing the value of continuous patronage to the efficiency of businesses. In a country with more than two hundred bus companies, it is puzzling that less than ten per cent of these have put in place a form of incentives or loyalty programs for passengers, while the rest rely heavily on undercutting fares to attract passengers. This exercise has resulted in a high turnover of companies in the industry which has resultantly kept the sector fragile. Companies in the developed world have registered tremendous success by initiating programs that enhance retention of passengers through improving the passengers' behaviour in preferring their services (Tao et al., 2016).

Public transport operators in Zimbabwe incorrectly assume that when passengers frequent their services, this highlights their loyalty to the brand. However, it is imperative to for this study also to evaluate this thinking as it has been proven elsewhere that this may not necessarily be the case as passenger frequency may be due to lack of alternative transport or having a phobia for driving long distances. The underlying factors that have created success in the retention of passengers for the few companies in the sector that have adopted the use of customer loyalty programs will be investigated during this study. Even though there has been insight from previous studies on passenger loyalty programs, these studies have not been explicitly applied to ascertain the value of loyalty programs in a developing economy like Zimbabwe and especially to an industry such as the road passenger transportation sector. The focus in the passenger transport sector has mainly focused on air travel (Vilkaite-Vaitone \& Papsiene, 2016). Paramount to the success of the road passenger transportation business is enhancing the desire of passengers to continue patronising the same 
brand over a long-term period (Lovelock \& Wirtz, 2007). Understanding that passenger preferences go beyond their behaviour towards a bus company becomes significant thereby allowing for the incorporation of likes, preferences and future requirements (Hossain et al., 2017). Most importantly is that research on all these factors in the past has focused on retail, air travel, hospitality industries and the identified sub-sector has very little work undertaken on it thereby providing a gap.

Research Objectives: This study aims to assess the value proposition of loyalty programs on customer relationship marketing in the Zimbabwean passenger transportation industry. Loyalty programs are proving to be invaluable in enhancing the retention of passengers (Jang \& Mattila, 2005) which inevitably allows for the improvement of organisational performance through repeat purchase. Marketing management has profoundly benefited from understanding that it is cheaper to keep an existing customer than to acquire a new one. Hence the importance now is being placed on retaining customers by marketing departments across the globe. The research was necessitated by the desire to ascertain how customer retention has become increasingly paramount to all industrial sectors including passenger transportation. Businesses in Zimbabwe have the unfortunate tendency to copy and paste procedures.

Applications and processes in use throughout the world without applying the necessary rationale for adoption. Loyalty programs in the passenger transportation industry may have come into effect accidentally and therefore, require research to understand more profoundly the value attached to them and their practical use in the country. The study will not be limited to evaluating the programs already in use but also to ascertain the value that the companies attain from to them in enhancing their organisational performance. By capacitating the passenger transportation companies' understanding of the utilisation of loyalty programs as a tool in customer relationship management, this study will establish a value for local businesses to improve efficiency. Therefore, the research shall be premised on the following questions.

Evaluating why Customer Loyalty Programs Necessary for the Business: It has been proven that it is by far cheaper to retain an existing customer than to pursue a new one (Jang \& Mattila, 2005). This notion rings true to the passenger transportation industry as well. By retaining passengers, companies improve their efficiency by reducing operational costs thereby developing sustainable brands. Furthermore, it is imperative for any business in a competitive environment to increase switching costs for customers by the introduction of loyalty programs that inhibit passengers from switching to alternative transporters (Singh \& Imran, 2012).

How are the Passenger Transportation Companies' Efficiently Utilising Loyalty Programs in Zimbabwe? In the context of the industry, there has been a weak uptake in the use of loyalty programs as a critical customer relationship management tool. Less than ten per cent of the companies in this sector have implemented an effective passenger loyalty program. Therefore, this study is essential in ascertaining how effective companies with these programs are in utilising them to gain a competitive advantage in an oversubscribed industry where passengers have an unlimited number of alternatives both legal and illegal.

What the Types of Loyalty Programs the Companies in Zimbabwe are using? Berman (2006) introduces us to the four broad-based categories of loyalty programs which provide incentives as follows;

\begin{tabular}{ll}
\hline Type 1 & discounts are processed immediately as customers make purchases; \\
\hline Type 2 & customers are proved with immediate gifts as extra for excess spending; \\
\hline Type 3 & $\begin{array}{l}\text { customers accumulate points which are redeemable at a certain point for specific } \\
\text { incentives; }\end{array}$ \\
\hline Type 4 & $\begin{array}{l}\text { Customers are placed into varying segments and get offered to vary individualised offers } \\
\text { through direct contact; }\end{array}$ \\
\hline
\end{tabular}

Predominantly, Zimbabwean companies utilise Berman's Type One category. However, there has been a small percentage of companies that have moved into divisions two, three and four, which has generated an advantage in the market for them. Similarly, it becomes essential therefore in the designing of these loyalty programs to make them create the necessary positive perception from passengers (Furinto et al., 2009). Lastly, due to an influx of the types of loyalty programs on the market, there has been a resultant enthusiasm for them from customers (Ferguson \& Hlavinka, 2007). The Zimbabwean economy has gone through several challenges over the years which have not spared the passenger transportation sector. Adopting modern 
techniques in increasing and sustaining patronages become imperative for the various brands in the market. It has to be noted that the information availed to us through the different research in the past on loyalty programs; we can identify the value they bring to our businesses. Players have had to introduce modern coaches and buses with different distinct services and products to enhance the safety and comfort of passengers. By encouraging repeat passenger patronage in the buses companies in the country are therefore improving the management of relationship marketing within the sector (Jang \& Mattila, 2005).

\section{Review of Related Literature}

Many of the literature reviewed spent much of their focus on how loyalty programs enhance organisational performance through customer retention. Measuring of competitive advantage and measuring their effects of financial performance (Magatef \& Tomalieh, 2015; Beck et al., 2015; Basera, 2014; Liu \& Yang, 2009; VilkaiteVaitone \& Papsiene, 2016). However, Berman (2006) and Furinto et al. (2009) introduced contrasting views that focus on how loyalty programs are designed as being the most valuable process in their success. McCall and McMahon (2016), however, present a different dimension of understanding what customers find useful. That notwithstanding, this study looked at the two angles in assessing the value loyalty programs bring both regarding organisational performance enhancement and the design structure of these. More scientific approaches are required for the modern business to attain positive organisational performance, which is achievable through innovation. Repeat purchases globally are now encouraged through incentives and rewards promoted in the majority of cases by using structured and systematic pattern analysis tools such as customer loyalty programs (Jang \& Mattila, 2005). In any line of business competition for customers is intense, which is no different for the passenger transportation sector.

It, therefore, follows that initiatives, especially over the past ten years, had to be put in place by transporters to manage to retain patronage while reducing operational costs (Jang \& Mattila, 2005). However, after January 2009, the country adopted the use of a multi-currency regime with the United States Dollar and the South African Rand being the most favoured currencies for trading. The Government of Zimbabwe also promulgated the Indigenisation and Economic Empowerment Act (2010) which reserved the passenger transportation industry for locals (Basera, 2014). This process witnessed the sudden influx of new players into the industry with the majority of players fitting into the existing traditional operational matrix. The number of transportation modes increased for the passengers which ultimately reduced switching costs for passengers (Thompson \& Chmura, 2015). Innovative transporters took the opportunity to introduce essential rewards and incentives, which has enhanced its competitiveness in retaining their passengers (VilkaiteVaitone \& Papsiene, 2016) while creating a niche market. However, it is still a herculean task for companies to increase switching costs for passengers due to the high supply of alternative transportation (both compliant and non-compliant). Positively though, the use of personal private vehicles for inter-city and inter-country travel has been drastically reduced.

\section{Literature Review of Customer Loyalty Programs}

Customer Loyalty Programs on Customer Retention: Magatef and Tomalieh (2015) focused on highlighting loyalty programs as essential tools for providing valuable benefits to both consumer and company. They portrayed consumer loyalty as being pivotal in ensuring companies attain both financial and operational success (Magatef \& Tomalieh, 2015). Relationship marketing management endears itself to creating a long-term bond between a company and its customers which enables the later to narrow their views on products (Singh \& Imran, 2012). Magatef and Tomalieh (2015) further expanded their research by evaluating retention which they emphasised plays a critical role in achieving healthy business growth. Customer loyalty programs are systematically structured marketing processes that initiate rewards as a mechanism to instigate repeat purchase (Sharp \& Sharp, 1997). The authors used the study to establish a critical understanding of the effects that loyalty programs have in retaining customers while explicitly focusing on Jordanian consumers. The authors applied the quantitative methodology by carrying out sampling using questionnaires. Interestingly, the authors used inferential surveying with the dependent variable being customer retention and independent variable loyalty programs (Easterby-Smith et al., 2012: 43). The research approach was that of creating cross-sectional samples addressing social, educational and occupational backgrounds to include varying their age range. 
Relationship Marketing and Loyalty Programs in the Global Markets: The study of Beck et al. (2015) focused on evaluating how different countries should apply customer relationships and loyalty to economic development and local culture. The authors expanded that customer relationship, and loyalty programs play a developmental role in enhancing sales and profits over time. The study introduces us to mechanisms on seller performance as listed below;

A) Inertia-Based - increases the advantages of previous consumer behaviour over new ones;

B) Comparison-Based - which assess what competitors are offering as a basis to measure existing programs.

C) Identify-Based - which focused more on individual customer characteristics being the source of customer-company relationships.

D) Communal-Based - focuses predominantly on the norms and set rules of exchange between companies and customers. Beck et al. (2015) wanted to create a clear understanding of how relationship marketing and loyalty programs may be affected by other factors that create a distinction on global markets. The authors used a research approach that was archival with the desire being to establish a grounded theory (Easterby-Smith et al., 2012: 58). The research, however, only managed to connect theory on multiple disciplines on the strategies that companies should have in place to address relationship marketing and loyalty programs. The authors did not, however, discuss the negative aspects of the different international strategy of loyalty programs as a tool of relationship marketing.

Types of Loyalty Programs: Berman (2006) developed four broad categories of loyalty programs which provide incentives as follows;

\begin{tabular}{ll}
\hline Type 1 & discounts are processed immediately as customers make purchases; \\
\hline Type 2 & customers are proved with immediate gifts as extra for excess spending; \\
\hline Type 3 & customers accumulate points which are redeemable at a certain point for specific incentives; \\
\hline Type 4 & $\begin{array}{l}\text { Customers are placed into varying segments and get offered to vary individualised offers } \\
\text { through direct contact; }\end{array}$ \\
\hline
\end{tabular}

Berman (2006) in this research focuses on issues that are pertinent in the industry whereby all operators with frequent traveller schemes are pursuing Type Three Loyalty Programs that make passengers accumulate a certain number of tickets before being legible for discounts. The research was predominantly premised on a grounded theory which was meant to ascertain the level of effective loyalty programs have in addressing the needs and requirements of customers. The study, however, left a gap in that the designing of loyalty programs should vitally address the needs of the consumer thereby increasing loyalty.

Designing Competitive Loyalty Programs: Furinto et al. (2009) highlights that loyalty programs are a marketing action that is meant to enhance customer retention. The authors also identify a need for loyalty programs to be designed and structured in such a way that they draw positive perceptions from consumers. Furinto et al. (2009) therefore introduce the value of using forecasts in the designing of loyalty programs. The authors applied two simultaneous quantitative methodologies to derive the value of monetary-based rewards and special treatment-based rewards, in an attempt to link the perceived effects of loyalty program designs to projected customer profitability (Furinto et al., 2009). The research discarded the notion that loyalty programs are of one static nature by indicating the differences brought about by the varying types of design having ardently different effects on consumers. However, there is still a gap created as the research was mainly experimental and lacked empirical testing and validation. Since the use of loyalty programs in the transportation industry is still relatively new, it would be prudent to introduce programs that are designed to attain the set objective of increasing passenger patronage.

Maximizing Customer Retention Through Loyalty Programs: Basera (2014) focuses on the fast food retail industry of Masvingo in Zimbabwe which has witnessed mushrooming of new entrants in an industry with well-established companies. The author also highlighted the need for the establishment of specific loyalty programs to enhance customer retention. The focus was made on the assertions of Jang and Mattila (2005) that retaining existing customers is far cheaper than acquiring new ones. The research intended to introduce an understanding of how non-monetary loyalty programs are being utilised by fast food retailers to enhance repeat purchase. The quantitative methodology was used to sample 120 consumers at three major fast food outlets to get a balanced understanding of the participants' perception of loyalty programs on offer. The 
author used the research to ascertain what incentive-based customer loyalty programs were on offered at the three most visited fast food outlets. The two issues that were not attended to by this study are; why the outlets have failed to find value in having loyalty programs and the outlets' patronage is affected by lack of loyalty program?

Competing Loyalty Programs: Liu and Yang (2009) focused their study on the increase in the number of loyalty programs on the market because of increasing competition, demanding and highly intelligent consumers. They highlight that companies need to improve relationship marketing continuously. The continued increase in loyalty programs in all the sectors of the economy has resulted in customers' enthusiasm for them increasing (Ferguson \& Hlavinka, 2007). The authors used the research to ascertain the performance of loyalty programs through assessing enabling and inhibiting factors to their success in improving companies' performance. They achieved this by focusing on the actual loyalty programs, the consumers and the competition (Liu \& Yang, 2009). The authors applied the archival research for the first study to ascertain the grounded theory (Easterby-Smith et al., 2012). A quantitative methodology was utilised for the second study by conducting factual surveys of airline customers (Easterby-Smith et al., 2012). Loyalty programs have a more positive effect if the companies providing them are dominant in the market (Liu \& Yang 2009). Market saturation was indicated as having relatively little impact on the reduction of the effectiveness of loyalty programs. The study relates well to the road passenger transportation industry. However, Liu and Yang (2009) did not cover the causes of the effects of loyalty programs as ascertained from the airline industry.

Customer Loyalty Programs on Organizational Performance: Vilkaite-Vaitone and Papsiene (2016) in their research proposed understanding how customer loyalty programs affect the performance of the organisation thereby determining the creation of relevant loyalty programs specific to the airline industry. They premised their research on the introduction by airlines of frequent flier miles in trying to enhance the retention of travellers (Jang \& Mattila, 2005). An archival research methodology was undertaken with systemic analysis of scientific literature and comparative analysis (Vilkaite-Vaitone \& Papsiene, 2016) which was seeking to empirically substantiate the theoretical framework for the airline industry. The authors focused on developing a narrative on the existence of a precise relationship between loyalty programs and organisational performance explicitly focusing on the Baltic States. The authors found that in relation to Baltic States airlines no significant link could be found between organisational performance and loyalty programs. Interestingly, the authors focused their sample on the one region, and that success of airlines does not only depend on loyalty programs but also on the relevance of services on offer.

Cultural Values on Loyalty Program Choice: Thompson and Chmura (2015) introduced a different dimension to our understanding of loyalty programs by making assertions that multinational corporations (MNCs) have to understand the role of cultural values in determining the choice of programs. Their findings highlighted that cultural values have a crucial role in influencing loyalty program choice by organisations while indicating that loyalty programs do not work similarly in all countries. The influence of cultural values needed to be understood in relating to consumer participation thereby becoming a strategy in enhancing the profitability of multinational corporations when they expand into new territories. Thompson and Chmura (2015) utilised the quantitative methodology through random experimental design (Easterby-Smith et al., 2012: 40) to manipulate the control group, therefore, producing accurate results. The study found that loyalty programs are context-specific; however, gaps were opened as not all cultural values were covered during the research. A high-involvement service like a coach or bus ticket may expand the choice of loyalty programs by varying cultures (Thompson \& Chmura, 2015).

What Matters to the Customer: Similarly, McCall and McMahon (2016) highlight in their research that customers have come to expect rewards in return for their patronage. In essence, customers, especially in the hospitality industry, show great resistance if their normally expected reward is altered forcing industry players to be innovative to keep customers engaged (McCall \& McMahon, 2016). The authors emphasise the need to appreciate that customers are adaptive and reactive regarding their expectation on the level of services, quality of products and their delivery. It, therefore, becomes paramount in their view for companies in the hospitality industry to adopt the use of loyalty programs that not only create attitudinal loyalty to the firm but also allow for an improvement in relationships (McCall \& McMahon, 2016). The authors utilised a 
quantitative methodology through an online survey of consumers (Easterby-Smith et al., 2012). One key finding of the study highlights that loyalty programs have become obligatory in the service and hospitality industries, gaps were found in need to examine the costs of varying loyalty member segments (McCall \& McMahon, 2016). Interestingly, for the passenger transportation industry understands how passengers (customers) level of loyalty is aligned with the management of the loyalty scheme is use (McCall \& McMahon, 2016).

Do Loyalty Programs Really Work: Hossain et al. (2017) use their research to ascertain how well customer loyalty programs work in an airline business explicitly focusing on Air Berlin, the success of Air Berlin in passenger retention was highlighted as being premised on essential services such as timing and pricing, which would be an exciting proposition for players in the road passenger transportation sub-sector (Hossain et al., 2017). The study was conducted using archival research methodology through secondary information collection from Air Berlin's official website and their annual reports for 2015 (Hossain et al., 2017) by seeking to empirically substantiate the theoretical framework in the case of the airline industry. Key findings of the study highlight that the airline through continuous innovation has managed to make the customer more loyal (Hossain et al., 2017). Moreover, success in retaining patronage is achievable by creating a competitive advantage over other players.

Theoretical and Empirical Reviews: Passengers just as with any other customer or consumer are adaptive and reactive to the services being rendered (McCall \& McMahon, 2016). Passengers have an expectation of comfort, safety, reliability and efficiency of service from transport operators, which therefore make an effort to keep them loyal to one brand that much more difficult to achieve. Highly contentious, however, is whether the companies understand the value of having loyal passengers through the various reward programs to attain the ability to draw both compliments and criticism to attain a high pedigree of services as espoused by their passengers. The companies are dolling out discounts that are just an unaccountable cost due to lacking the infrastructure to harness passenger retention and measure company performance (Beck et al., 2015; Magatef \& Tomalieh, 2015). In essence, the uptake of the use of multi-currencies in Zimbabwe (Basera, 2014) introduced the need for transporters to enhance relationship marketing management by adopting the use of loyalty programs as a tool.

However, extensive improvements both in the design of the programs and application are required to attain the set objectives of enhancing competitiveness (efficiency) and brand loyalty (Vilkaite-Vaitone \& Papsiene, 2016; Liu \& Young, 2009; Hossain et al., 2017). The literature review was undertaken to indicate how important firms feel loyalty programs are in firstly understanding the requirements of their customers and secondly in coming up with mechanisms to reward them for their loyalty. Our country seeks to develop a modern passenger transportation system; it will become essential to understand the value of passenger retention in enhancing organisational performance. Basera (2014) highlights that the deficiency in the country is mainly due to the implementation of loyalty programs that should encourage loyalty as the influx of new players continue to make it easy for passengers to switch providers. In the long run, investigations will highlight that it is important to design loyalty programs that increase customer-company relationships (Kang et al., 2015).

Table 1: Summary of Literature

\begin{tabular}{|c|c|c|c|c|c|c|}
\hline $\begin{array}{l}\text { Authors } \\
\text { (Date) }\end{array}$ & & Research Topic & $\begin{array}{l}\text { Theoretical } \\
\text { Framework }\end{array}$ & Methodology & Main Findings & Research Gap \\
\hline $\begin{array}{l}\text { Magatef } \\
\text { Tomalieh } \\
(2015)\end{array}$ & $\&$ & $\begin{array}{ll}\text { Impact } & \text { of } \\
\text { Customer } & \\
\text { Loyalty } & \\
\text { Programs } & \text { on } \\
\text { Customer } & \\
\text { Retention } & \\
\end{array}$ & $\begin{array}{l}\text { How customer } \\
\text { retention } \\
\text { improves the } \\
\text { performance of } \\
\text { the } \\
\text { organisations }\end{array}$ & Quantitative & $\begin{array}{l}\text { Loyalty } \\
\text { programs are } \\
\text { essential tools } \\
\text { in CRM }\end{array}$ & $\begin{array}{l}\text { The sample was } \\
\text { in one country } \\
\text { hence } \\
\text { challenging to } \\
\text { generalise. }\end{array}$ \\
\hline
\end{tabular}




\begin{tabular}{|c|c|c|c|c|c|}
\hline $\begin{array}{l}\text { Beck et al. } \\
(2015)\end{array}$ & $\begin{array}{l}\text { Understanding } \\
\text { RM and Loyalty } \\
\text { Programs } \\
\text { Effectiveness in } \\
\text { Global Markets }\end{array}$ & $\begin{array}{l}\text { Introduce } \\
\text { mechanisms } \\
\text { that measure } \\
\text { company } \\
\text { performance }\end{array}$ & Archival & $\begin{array}{l}\text { Multi-faceted } \\
\text { understanding } \\
\text { of strategies } \\
\text { that companies } \\
\text { need for } \\
\text { relationship } \\
\text { marketing. }\end{array}$ & $\begin{array}{lr}\text { Cultural } & \text { factors } \\
\text { affecting } & \text { RM } \\
\text { were } & \text { not } \\
\text { adequately } & \\
\text { investigated } & \end{array}$ \\
\hline Berman (2006) & $\begin{array}{l}\text { Developing } \\
\text { effective } \\
\text { customer } \\
\text { loyalty } \\
\text { programs }\end{array}$ & $\begin{array}{l}\text { Identification of } \\
\text { broad-based } \\
\text { categories of } \\
\text { loyalty } \\
\text { programs }\end{array}$ & $\begin{array}{l}\text { Grounded } \\
\text { Theory }\end{array}$ & $\begin{array}{l}\text { Assessing the } \\
\text { effectiveness of } \\
\text { loyalty } \\
\text { programs in } \\
\text { meeting the } \\
\text { needs of } \\
\text { customers. }\end{array}$ & $\begin{array}{l}\text { Need for the } \\
\text { creation of } \\
\text { unique loyalty } \\
\text { programs }\end{array}$ \\
\hline $\begin{array}{l}\text { Furinto et al. } \\
(2009)\end{array}$ & $\begin{array}{l}\text { Designing of } \\
\text { loyalty } \\
\text { programs: How } \\
\text { types of } \\
\text { programs affect } \\
\text { customer equity }\end{array}$ & $\begin{array}{l}\text { The effects of } \\
\text { monetary-based } \\
\text { rewards against } \\
\text { special } \\
\text { treatment } \\
\text { rewards }\end{array}$ & Quantitative & $\begin{array}{l}\text { Program utility } \\
\text { is higher in } \\
\text { banks because } \\
\text { incentives are } \\
\text { monetary. }\end{array}$ & $\begin{array}{l}\text { Use of } \\
\text { alternative } \\
\text { methods to } \\
\text { improve on } \\
\text { generalisation. }\end{array}$ \\
\hline Basera (2014) & $\begin{array}{l}\text { Maximizing } \\
\text { Customer } \\
\text { Retention } \\
\text { through Loyalty } \\
\text { Programs }\end{array}$ & $\begin{array}{l}\text { Understanding } \\
\text { how loyalty } \\
\text { programs are } \\
\text { being used for } \\
\text { customer } \\
\text { retention. }\end{array}$ & $\begin{array}{l}\text { Quantitative } \\
\text { (Descriptive } \\
\text { Research) }\end{array}$ & $\begin{array}{l}\text { Incentive-based } \\
\text { loyalty } \\
\text { programs not } \\
\text { being used as a } \\
\text { tool for } \\
\text { customer } \\
\text { retention. }\end{array}$ & $\begin{array}{l}\text { Use of loyalty } \\
\text { programs would } \\
\text { increase } \\
\text { customers } \\
\text { switching. }\end{array}$ \\
\hline $\begin{array}{l}\text { Liu \& Young } \\
(2009)\end{array}$ & $\begin{array}{l}\text { Impact of } \\
\text { Market } \\
\text { Saturation, } \\
\text { Share and } \\
\text { Category } \\
\text { Expandability } \\
\text { on Competing } \\
\text { Loyalty } \\
\text { Programs }\end{array}$ & $\begin{array}{l}\text { How the firm's } \\
\text { loyalty } \\
\text { programs are } \\
\text { affected by its } \\
\text { competitive } \\
\text { positioning and } \\
\text { market } \\
\text { saturation. }\end{array}$ & Quantitative & $\begin{array}{l}\text { Loyalty } \\
\text { programs are } \\
\text { an essential } \\
\text { CRM tool. }\end{array}$ & $\begin{array}{l}\text { Other factors } \\
\text { such as the } \\
\text { degree of } \\
\text { marketing, the } \\
\text { existence of } \\
\text { switching costs } \\
\text { were not } \\
\text { properly taken } \\
\text { into account }\end{array}$ \\
\hline $\begin{array}{l}\text { Vilkaite- } \\
\text { Vaitone } \\
\text { Papsiene } \\
(2016)\end{array}$ & $\begin{array}{l}\text { Customer } \\
\text { Loyalty } \\
\text { Program on } \\
\text { Organisational } \\
\text { Performance }\end{array}$ & $\begin{array}{l}\text { What influence } \\
\text { loyalty } \\
\text { programs have } \\
\text { on the } \\
\text { organisational } \\
\text { performance of } \\
\text { airlines }\end{array}$ & $\begin{array}{l}\text { Archival } \\
\text { Research }\end{array}$ & $\begin{array}{l}\text { No significant } \\
\text { link was found } \\
\text { between } \\
\text { organisational } \\
\text { performance } \\
\text { and use of } \\
\text { loyalty } \\
\text { programs }\end{array}$ & $\begin{array}{l}\text { Organisational } \\
\text { performance is } \\
\text { dependent on } \\
\text { other factors }\end{array}$ \\
\hline $\begin{array}{l}\text { Thompson } \\
\text { Chmura } \\
\text { (2015) }\end{array}$ & $\begin{array}{l}\text { Loyalty } \\
\text { Programs in } \\
\text { Emerging and } \\
\text { Developing } \\
\text { Markets }\end{array}$ & $\begin{array}{l}\text { MNCs need to } \\
\text { understand the } \\
\text { role of cultural } \\
\text { values in } \\
\text { developing } \\
\text { appropriate } \\
\text { loyalty } \\
\text { programs }\end{array}$ & $\begin{array}{l}\text { Quantitative } \\
\text { (random } \\
\text { experiment) }\end{array}$ & $\begin{array}{l}\text { Loyalty } \\
\text { programs are } \\
\text { context-specific }\end{array}$ & $\begin{array}{l}\text { More cultural } \\
\text { values were } \\
\text { omitted in the } \\
\text { study }\end{array}$ \\
\hline
\end{tabular}




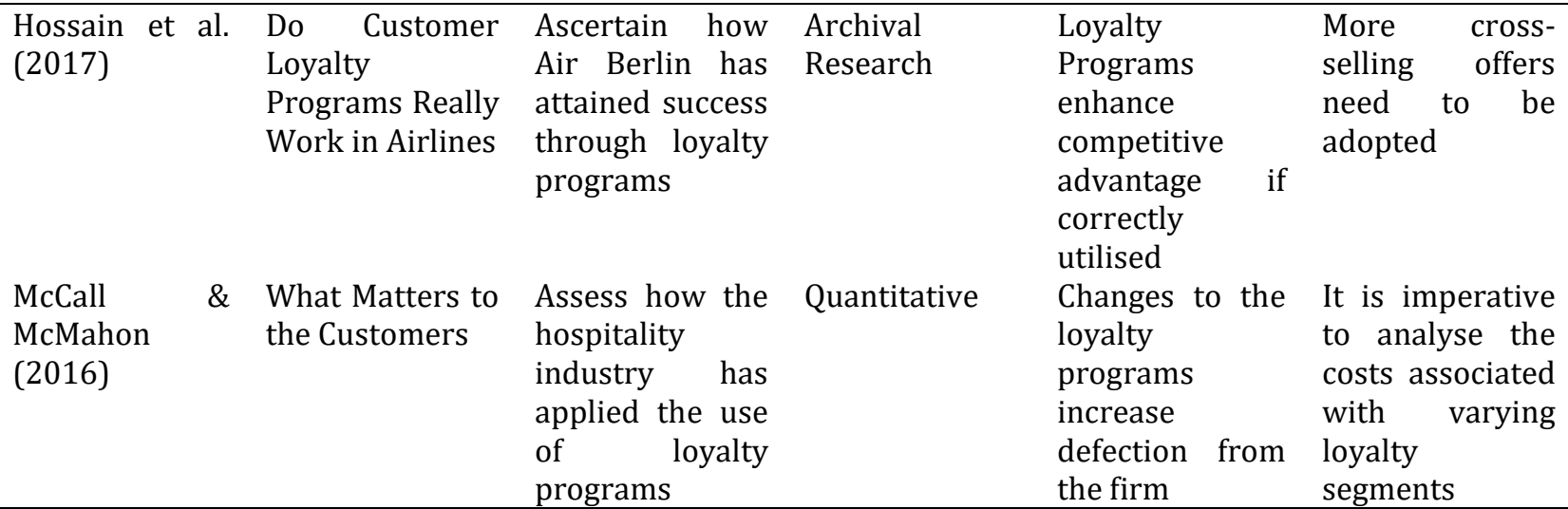

\section{Methodology}

This study aims to investigate whether the companies in the passenger transportation sector in Zimbabwe are doing well in utilising loyalty programs as a tool for managing relationship marketing. Though loyalty programs in other industry have proven valuable in enhancing customer retention (Jang \& Mattila, 2005) which inevitably improves organisational performance through repeat purchase, this needs to be investigated by the chosen industry. Zimbabwe is a developing country, which also applies that the economic environment is still in the developmental stage hence most concepts are still in their infancy including the use of loyalty programs. Though, the use of loyalty programs in the road passenger transportation industry may seem at this stage to have come about accidentally, assessing their value in attaining the objective of passenger retention is still essential.

Research Design and Methodology: The capacity of passenger transportation companies' understanding of the utilisation of loyalty programs needs to be enhanced for them to be appreciated as critical tools in customer relationship management, this study was aimed at establishing values for local businesses to improve efficiency. To comprehensively ascertain the value of passenger loyalty programs in Zimbabwe, the study adopted the underlying constructivist philosophy of assuming that there are no absolute truths and therefore necessitating an investigation to establish my claim to the truth (Awolusi, 2014; Awolusi, Magaji, \& Odunlami, 2015). Thus one of the primary research approaches for my study will be action (co-operative inquiry) by interviewing the leaders of my targeted companies who by role have the responsibility and authority to affect or implement the necessary changes (Easterby-Smith et al., 2012). The qualitative methodology is the most appropriate for this research. Qualitative research is different in that it arrives at its findings by incorporating reality instead of using quantification means (Strauss \& Corbin, 1990).

The present study intends to establish an understanding of the perception of companies regarding the value created by using loyalty programs. In this regard, the purpose, size of the group to be studied, the expectancy of subjectivity since I am known to the respondents prescribe that this research uses qualitative research. In concluding the study, the intention is to generate valuable findings from a written report showing the connection between business growth and loyalty programs' ability to retain patronage (Lichtman, 2006). Furthermore, the present study also used in-depth interviews to draw out the views, interpretation, and mindset of the senior executives of the ten identified bus companies thereby evaluating the role loyalty programs in their organisations (Easterby-Smith et al., 2012: 126). Since only people with specific knowledge of the institutions were deemed capable of giving valuable opinion about the subject matter, a one on one interview was most ideal. However, since the present study intends to satisfy and meet a specific criterion, hence purposive homogeneous sampling technique was adopted (Easterby-Smith et al., 2012).

Data Collection and Analysis: In assessing the benefits of passenger loyalty programs, the study appled the qualitative methodology. The method accessed the views, interpretation, and mindset of senior executives of the identified companies to evaluate the role loyalty programs within their firms (Easterby-Smith et al., 2012). Furthermore, to enhance data collection method's objectivity, the study utilised semi-structured types of interviews which was guided but still open to provide a higher degree of confidentiality to the participants 
(Easterby-Smith et al., 2012). It is vital for the qualitative data to be condensable into a format that allows simple presentation of results, findings and recommendations in a manner that convinces others (EasterbySmith et al., 2012). In that regard, the study utilised the grounded analysis which offers broader approaches to data analysis with theory developing from the data collection to analysis (Easterby-Smith et al., 2012). The approach remain inductive to compliment the grounded analysis by ensuring that no predetermined theory, structure or framework is in place but only by using the actual data collected to institute the structure of report (Burnard et al., 2008). All relevant data were labelled according to its possible relevance to the study thereby building a theory that intimately highlights the evidence of the importance of loyalty programs in the passenger transportation sub-sector (Lawrence \& Tar, 2013).

Validity Analysis, Practical and Ethical Challenge Mitigation: As qualitative research involves human beings understanding human beings, which from the initial stage provides a necessary subjective practice. The first four questions of the interviews established a reasonable level of validity. In ascertaining how valuable the chosen companies' loyalty programs are to their passengers, the study was able to attain efficacy. For example, qualitative research prescribes a researcher-participant relationship to be established which bring apparent ethical concerns namely; respect for privacy, need for developing transparent, open and honest interviews and avoiding both misinterpretation and misrepresentation (Warusznski, 2002). The data collected through interviews were, therefore, kept confidential at all times by securing data storage methods, removal of identifier components where necessary (Orb et al., 2001). In addition, qualitative research entails the investigation of the situation in a real-life context (Yin, 2003), which bring about a lack of control for researchers. Consideration has to be given to participants as they are the primary data source. Hence, selecting and recruiting participants will become imperative regarding their willingness and ability to expunge their time for the study (Wicks \& Whiteford, 2006).

Presentation of Data Collected: As highlighted by Easterby-Smith et al. (2012), the present study adopted the seven main stages of the grounded analysis, namely: Familiarization - sticking to the focus of the study and what the data is inferring through assessing the views expressed by my respondents; Reflection - making sure that the data supports existing knowledge and the effects it has on this knowledge; Conceptualization precise and straightforward open coding of respondents' ideas; Cataloguing concepts - transferring the respondents' thoughts through manual methods into a database; Re-coding - identify matching properties by reassessing the original data against the synthesised data; Linking - enhance the emerging patterns between concepts by developing theoretical codes that establish the analytical framework and explanations; and Reevaluation - it is imperative for any process to assess any areas that need tweaking or improvement (Blazi \& Awolusi, 2020; Matira \& Awolusi, 2020). It remains essential to establish a tabular presentation of collected data that enhances the understanding of others by highlighting the central units of analysis. The preferred approach reports significant discovery under each central theme (Burnard, 2004).

Data Presentation Format and Design: The data was presented both in tabular and text form. Tables are much easier because of their ability to indicate the presence or absence of specific characteristics. Text, as the data was not be complicated, therefore, will be readily incorporated into my research. The categorisation is pivotal in the presenting data subjectively as its epistemological position (Bergman \& Coxon, 2005). It is important to validate data against the research question as this influence the types of categories to be used as well as the sorting rules (Bergman \& Coxon, 2005). Sorting was undertaken to assign empirical observations about their similarities or lack thereof. As the research has been undertaken to ascertain the value of loyalty programs, to avoid misinterpretation, the data was then sorted along with the following variables - loyalty programs, incentives, customer relationship management, marketing and brand management. However, that socio-cultural influences categorisation processes in two varying ways; shared values - values, norms and ideologies, and through the actual immediate context (Bergman \& Coxon, 2005) which ultimately plays a pivotal role in influencing the interpretation of the research. Relating the categories to the Zimbabwean context was, therefore, important in reducing the effects of misinterpretation.

\section{Results and Discussion of Findings}

This section highlights the data analysis and findings from ten questionnaires completed by Managing Directors, General Managers and Regional Managers of the nine leading bus companies operating in 
Zimbabwe. The in-depth interviews were conducted through physical visits to the chosen operator's offices throughout Zimbabwe. The purpose of the study was to understand the extent to which the use of loyalty programs by a selected group of passenger transportation companies have influenced their relationship marketing and operational efficiency. The collected data was analysed to identify, describe and explore the relationship between enhanced organisational performance (both financial and operational) and efficient use of loyalty programs by passenger transporting companies in Zimbabwe.

Description of Study Sample: Data was obtained from self-administered questionnaires, completed by nine executives $(\mathrm{e}=9)$, a ninety per cent $(90 \%)$ response rate.

Figure 1: Distribution of Study Sample by Job Title

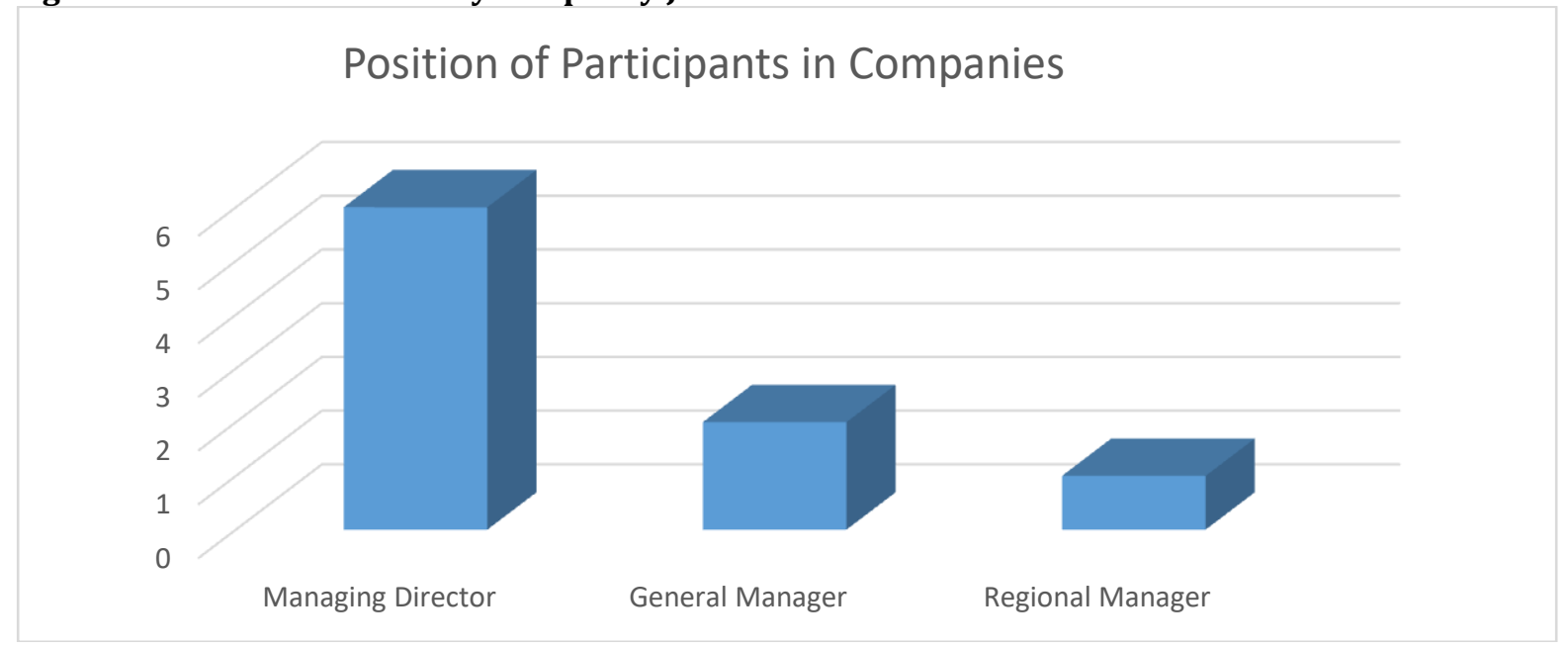

The majority of the participants (67\%) are the actual decision-makers in the selected companies on the tools that should be used in relationship marketing. Eighty-nine per cent (89\%) the respondents highlighted the use of what Berman (2006) described as category type three loyalty program concept, which necessitates that passengers accumulate and produce between five and ten tickets to attain either a fifty (50\%) or hundred (100\%) discount on next travel. Only eleven per cent $(11 \%)$ of the respondents utilised type one of Berman's four broad-based categories of loyalty programs which provides an immediate discount as passengers' purchase travel tickets. However, only twenty-two per cent $(22 \%)$ of the sample highlighted that they provide passengers with a specific window period of twelve (12) months within which the accumulation and product of tickets need to occur. The rest of the respondents (78\%) highlighted that as long as tickets are produced within a reasonable period even beyond a year passenger will be eligible for discount. Forty-four per cent $(44 \%)$ of respondents highlighted that they have an established database of passengers, with the booking system calculating the level of discount to be given automatically. The rest of the participants do not have a database of their passengers, therefore, depending solely on the passenger returning out of their own volition for repeat business.

Testing the Hypotheses: Ha. The first hypothesis claims that the majority of modern businesses utilise loyalty programs as a tool for relationship management. The claim stems from the observations of Kang and Mattila (2005) that it is three times cheaper to keep an existing passenger against acquiring a new one. Therefore, the assumption would have been companies in the transportation industry in Zimbabwe would find it necessary to introduce a passenger relationship management tool such as loyalty programs to attain this saving. However, in this situation, we are obliged to accept a null hypothesis, meaning that though the respondents felt it was vital to retain passengers, their approach is mainly centred on the alteration downwards of the passenger fare. Hb. The second hypothesis deals with loyalty programs helping in improving the company's operational efficiency through the effective application. Furthermore, it is a necessity for the research to maintain high ethical standards by making sure that all gathered information 
remains anonymous. This was achieved by making sure that we sustained the trust of all participants whose confidence we already enjoyed (Easterby-Smith et al., 2012). Secondly, the research plays a vital role.

In developing an understanding of the value drawn from loyalty programs in the sector, therefore, defining the participant ability to trust the intentions and objectivity of the interviews was attained through our already existing social interaction (Easterby-Smith et al., 2012). The question is in fact whether loyalty programs increase market share, therefore, increasing the number of passengers for the selected companies. On the sampled group, however, the coefficient is not high enough to highlight any correlation mainly due to the use of tools that cannot be related to loyalty programs by the majority of respondents (56\%). Hc. The last hypothesis is aimed at discovering whether how much loyalty programs influence the financial performance of selected passenger transportation companies in Zimbabwe. Similarly, the use of discounts, fare reduction is more predominant in Zimbabwe hence we cannot safely identify the correlation between improved financial performance and loyalty programs of the sampled companies. It is inevitably apparent that what the majority of companies are using in Zimbabwe as customer relationship management tools cannot be safely be identified as loyalty programs. The results of the data indicate the distribution of discount to passengers per company (Table 2).

Table 2: Distribution of Discount to Passengers per Company

\begin{tabular}{|c|c|c|c|c|c|c|}
\hline Company & $\begin{array}{l}\text { Name of } \\
\text { Scheme }\end{array}$ & $\begin{array}{l}\text { Program } \\
\text { Principle }\end{array}$ & $\begin{array}{l}\text { No of } \\
\text { Tickets } \\
\text { to } \\
\text { Qualify }\end{array}$ & $\begin{array}{l}\text { No of } \\
\text { Passengers } \\
\text { on the } \\
\text { Scheme as } \\
\%\end{array}$ & $\begin{array}{l}\text { Percentage } \\
\text { Discount }\end{array}$ & $\begin{array}{l}\text { Moment of } \\
\text { Reward's } \\
\text { Usage }\end{array}$ \\
\hline Intercape Mainliner & $\mathrm{Nil}$ & $\begin{array}{l}\text { Frequency } \\
\text { reward }\end{array}$ & 10 & $87 \%$ & $100 \%$ & Immediate \\
\hline Eagleliner Coaches & $\begin{array}{l}\text { Mahala } \\
\text { Travellers } \\
\text { Club (MTC) }\end{array}$ & $\begin{array}{l}\text { Frequency } \\
\text { reward }\end{array}$ & 10 & $75 \%$ & $50 \%$ & Immediate \\
\hline Intercity Xpress & $\begin{array}{l}\text { Mahala } \\
\text { Travellers } \\
\text { Club (MTC) }\end{array}$ & $\begin{array}{l}\text { Frequency } \\
\text { reward }\end{array}$ & 10 & $80 \%$ & 50 & Delayed \\
\hline Revival Motorways & $\begin{array}{l}\text { Free Ticket } \\
\text { Club }\end{array}$ & $\begin{array}{l}\text { Frequency } \\
\text { reward }\end{array}$ & 5 & $65 \%$ & $100 \%$ & Immediate \\
\hline $\begin{array}{l}\text { Munenzwa } \\
\text { Service }\end{array}$ & Nil & $\begin{array}{l}\text { Frequency } \\
\text { reward }\end{array}$ & 5 & $50 \%$ & $100 \%$ & Immediate \\
\hline King Lion Motorways & $\begin{array}{l}\text { KL Frequent } \\
\text { Traveller }\end{array}$ & $\begin{array}{l}\text { Frequency } \\
\text { reward }\end{array}$ & 10 & $100 \%$ & $100 \%$ & Immediate \\
\hline Chichewa Tours & $\begin{array}{l}\text { Frequent } \\
\text { Traveller }\end{array}$ & $\begin{array}{l}\text { Frequency } \\
\text { reward }\end{array}$ & 6 & $30 \%$ & $100 \%$ & Immediate \\
\hline Delta Coaches & $\begin{array}{l}\text { Frequent } \\
\text { Traveller }\end{array}$ & $\begin{array}{l}\text { Frequency } \\
\text { reward }\end{array}$ & 6 & $10 \%$ & $100 \%$ & Immediate \\
\hline Tombs Motors & $\begin{array}{l}\text { Frequent } \\
\text { Traveller }\end{array}$ & $\begin{array}{l}\text { Frequency } \\
\text { reward }\end{array}$ & 6 & $60 \%$ & $100 \%$ & Immediate \\
\hline Pioneer Coaches & Nil & Nil & $\mathrm{Nil}$ & Nil & Nil & Nil \\
\hline
\end{tabular}

To assess whether having an established loyalty program has positive effects on passenger transport companies' market share (customer relationship management) (Ha), operational efficiency (Hb) and profitability (Hc) the above data was extrapolated. The data indicate that all sampled companies though, providing some sought of a loyalty scheme, this cannot easily be reduced to being a loyalty program. VilkaiteVaitone and Papsiene (2016) correctly highlight that there is little proof that organisational performance is directly affected by loyalty programs. Similarly, in the case of Zimbabwean companies sampled the findings are that the frequent traveller programs currently in use do not exert any positive influence on the financial performance of the company. Neither does it improve operational efficiency through increasing repeat business or monitoring the travel patterns of passengers. 
Table 3: Chi-Square of the Relationship between Loyalty Program and Customer Relationship Management (Ha), Operational Efficiency (Hb) and Profitability (Hc)

Loyalty Program and Customer Relationship Management

$\begin{array}{lrrr}\text { Low } & 4(33.3) & & 8(66.7) \\ \text { Moderate } & & 2(20.0) & 8(80.0) \\ \text { High } & 4(34.2) & & 7(45.2) \\ \text { Statistic } & \text { DF=1, } \quad \chi^{2}=0.4889 & p>0.05 & \end{array}$

Loyalty program and operational efficiency

$\begin{array}{lll}\text { Low } & 4(28.6) & 10(71.4) \\ \text { Moderate } & 4(18.2) & 18(81.8) \\ \text { High } & 8(23.5) & 26(76.5)\end{array}$

Statistic $\quad \mathrm{DF}=4, \quad \chi^{2}=2.3481 \quad \mathrm{p}>0.05$

Loyalty program and profitability

Low

Moderate

High

Statistic
$55(77.5)$

$11(84.6)$

$10(76.2)$

The Chi-square results in table 3 clearly validated the three null hypotheses at a $5 \%$ level of significance. Hence, we can conclude based on the Chi-Square results of a positive significant relationship between loyalty program and customer relationship management ( $\mathrm{Ha})$, operational efficiency ( $\mathrm{Hb})$ and profitability ( $\mathrm{Hc}$ ). However, all respondents to the research indicate having adopted the current discount programs in use over the last five (5) years. In summary, the significant relationship can be said to exist between the passengers and the companies providing them with transport services due to the use of loyalty programs namely the frequent traveller scheme. The manner in which the scheme is currently administered through the production of previous tickets indicates a well-established relationship between the selected companies and their passengers. However, regarding business efficiency and profitability, no significant correlation can directly be shown. The table below highlights the results of the hypotheses of the study.

Table 4: Results of Hypotheses of the Study

\begin{tabular}{llll}
\hline Company & $\begin{array}{l}\text { Ha }- \text { use of loyalty } \\
\text { programs as a tool for RM }\end{array}$ & $\begin{array}{l}\mathbf{H}_{\mathbf{b}} \text { - the value of loyalty } \\
\text { programs in enhancing } \\
\text { operational efficiency }\end{array}$ & $\begin{array}{l}\text { Hc the Financial } \\
\text { influence of } \\
\text { programs }\end{array}$ \\
\hline Intercape Mainliner & High & Low & Low \\
Eagleliner Coaches & High & High & Moderate \\
Intercity Xpress & High & High & Moderate \\
Revival Motorways & Moderate & Low & Low \\
Munenzwa Bus Service & Moderate & Low & Low \\
King Lion Motorways & High & Low & Low \\
Chichewa Tours & Low & Low & Low \\
Delta Coaches & Low & Low & Low \\
Tombs Motors & High & Moderate & Low \\
Pioneer Coaches & Nil & Nil & Nil \\
\hline
\end{tabular}

Interpretation and Discussion of Findings: The loyalty programs in use do not adequately play the role of a passenger relationship management tool as the application serves no purpose other than to appreciate repeat business hence they do not conform to the narrative introduced to us by Basera (2014) of applying loyalty programs to harness customer retention. All nine companies interviewed draw very little information on the travelling patterns of the beneficiaries of the discount as the process is done manually and no data is collated for future use. Interestingly one of the facets of loyalty programs is to measure the performance of the 
company using them (Beck et al., 2015) which is lost to the transporters. The operators are utilising Berman's type three discount programs which allow passengers to accumulate tickets before accessing discounts. The transporters, unfortunately, are not taking advantage of all four broad-based categories of loyalty programs, which could improve the cross-selling of services thereby enhancing business efficiency as espoused by Berman (2006). Thereby enhancing passenger-company identification and improve loyalty to the brand. It has to be noted that the companies have already achieved half of the work of attaining the retention of passengers as there is consistent use by passengers of the same respective companies. Therefore, obtaining cost-cutting measures of keeping old passengers is achievable (Magatef \& Tomalieh, 2015).

All nine companies utilise the frequent traveller discount systems which in the majority of cases is applicable through passengers keeping and presenting to the company a certain number of tickets to enjoy either a fifty $(50 \%)$ or hundred $(100 \%)$ per cent on their next travel. This aspect of providing discounts fits perfectly into the narrative of being a monetary-based rewards scheme (Furinto et al., 2009). The influx of new operators has forced the hand of traditional players in adopting loyalty program initiatives as a way of safeguarding their traditional market share. Though, there is room for further improvements what has been essential is the start. In all the interviews though, respondents highlighted lack of significant linkage between the use of loyalty programs and their ability to create a distinct competitive advantage of the rival companies which agree with the findings of Vilkaite-Vaitone and Papsiene (2016), with other factors being highlighted as being paramount for achieving desired advantages. Travel in Zimbabwe has been reduced to a necessity due to economic challenges, which has cut the market by more than half over the past couple of years. The remaining half wants to pay as little as possible which has resulted in undercutting of fares which links to the need of understanding the economic and cultural values of the target market as envisaged by Thompson and Chmura (2015) when they highlighted that loyalty programs should ideally be context-specific.

Operators could utilise this knowledge when crafting loyalty schemes that not only address specific competitive edge requirements but also allowing their companies to attain a higher percentage of passenger retention. All nine companies have however managed to attain one aspect of loyalty programs that of brand loyalty (Magatef \& Tomalieh, 2015), but unfortunately, have not enhanced it to a point where it addresses growth in profitability and improvement of operational efficiency. Lastly, there is a worrying trend within the companies of not being sure if the passengers' perception of the schemes in operation is positive or negative. Furthermore, research indicates that all the participating companies use a monetary-based reward system, which their passengers prefer (Furinto et al., 2009). Critically, respondents all highlighted the need to improve the current loyalty programs in use. In the majority of cases (ninety per cent) their passengers were requesting for the reduction in the number of tickets required for them to qualify for a discount. This knowledge should, therefore, enable transporters to ascertain the value of adopting and using loyalty programs appropriately thereby enhancing their competitive advantage in a fast-paced world economy. However, it has to be noted that altering reward tier requirements both positive and negative depending on the perception of the recipient may increase the defection of passengers from the company (McCall \& McMahon, 2016).

\section{Conclusion, Implications and Recommendations}

Summary and Conclusion: The study observed the current utilisation of tools that the selected companies deem to be loyalty programs. The literature review concentrated on the role of loyalty programs in all facets of the economy and did not specifically focus on the transportation industry. Qualitative research was undertaken initially targeting ten (10) of the leading passenger transportation companies in Zimbabwe. However, only nine (9) were successfully interviewed. Six of the nine respondents were managing directors (principal officers of their respective companies); two were general managers and the final a regional manager. Permission to undertake interviews was granted by the Coach and Bus Operators Association (CBOA), an organisation made up of bus operators operating in the Southern African Development Community (SADC) headquartered in Harare, Zimbabwe. Prior, to conducting interviews respondents were asked to sign a Participant Consent Form.

The research intended to understand the use of loyalty programs in the daily operation of the selected companies while identifying their value both in attaining passenger loyalty, improving business efficiency and 
lastly enhancing profitability. The value of loyalty programs was therefore observed using in-depth interviews within the parameters of the case study (i.e. identification of existing scheme, type of programs in place, the overall value generated in market share, ability to stifle competition), codified and hypotheses tested via Chi-square inferential method. The study provides support for the importance of loyalty programs as passenger relationship management tools if appropriately applied and implemented. Loyalty programs offer companies across industrial sectors with useful benefits such as brand loyalty, business efficiency due to enhanced planning and profitability due to increase in patronage from passengers who are less sensitive to the marketing efforts of competing brands (Aaker, 1992).

Recommendations: Based on the Chi-Square results, the study concluded of a positive significant relationship between loyalty program and customer relationship management, operational efficiency and profitability in the Zimbabwe transportation loyalty programs. Transporters need to know how to initiate loyalty programs that not only reflect the passengers' preferences and travel patterns but also competitive enough to scare away rivals while providing passengers with sufficient motivation to remain loyal to them. To attain this goal here are the recommendations: Our research has already indicated that passengers prefer monetary-based incentives to special treatment-based ones. Implementing and administering loyalty programs involves high costs and risks (Furinto et al., 2009) hence the need for companies to understand the relationship modes as they affect their passengers. Though, carrying the risk of being labelled as promotional programs (Yi \& Jeon, 2003), monetary rewards can be designed in a manner that they do not provide instant rewards (Furinto et al., 2009) as is already the case in the industry with free tickets only accruing after several tickets. Lastly, the loyalty programs must be designed in a manner that nurtures a long-term fruitful relationship between the company and its passengers (Morgan \& Hunt, 1994). It, therefore, becomes imperative for passenger transportation companies in the country to develop passenger databases which will store information while allowing for ease of extraction. It is encouraged for companies in the industry to maintain a non-contractual relationship with the passengers (though having lower or no switching costs).

It forces the company to maintain a high level of service delivery. Companies do not want passengers to utilise their services just because it is convenient as this would be spurious loyalty (Dick \& Basu, 1994). It is becoming imperative that companies start looking at introducing a different type of rewards scheme. Achievable by creating an exclusive club of passengers who are upgraded to special treatment rewards which are designed to provide comfort and peace of mind (Furinto et al., 2009). In the context of the industry, this could be achieved by upgrading passengers from a semi-luxury coach to a luxury one where companies have two different services. One of the significant developments that need to occur in the market is the issuance of loyalty program cards to passengers, similar to those found in airlines and retail industries. The card would also increase the efficiency of redeeming points while strengthening the monitoring of passenger travel patterns (Magatef \& Tomalieh, 2015). The card may also be used to segment status of the passenger (i.e. students, professionals, pensioners etc). Critical to any business growth understands the needs of customers through creating avenues for their views and suggestions to be heard. The industry should adopt the use of transparent feedback systems that not only address lodging of complaints but also of ideas (Magatef \& Tomalieh, 2015). The loyalty program in use should award points to existing passengers when they refer new passengers to the company. Adopting referrals enables companies to both keep existing customers while acquiring new ones far cheaper than initiating a capital-intensive marketing program.

In summary, relationship marketing management has grown globally over the last couple of decades. Success has been constructed by making sure that companies can manage and improvement in income generation while reducing operational costs. Jang and Mattila (2005) correctly assert that loyalty programs should encourage customer's behaviour toward repeat purchase which is fundamental to enhancing customer retention. In the context of the road passenger transport industry and the country in general, it should therefore also apply that the use of loyalty programs should improve business performance in all facets. However, the use of loyalty programs in the industry is relatively in its infancy and has a long way to develop. Regardless, the value of loyalty programs in enhancing competitive advantage and improving operational efficiency due to the increase in income and profitability is proven (Vilkaite-Vaitone \& Papsiene, 2016; Singh \& Imran, 2012). 
Companies need to understand the use and effectiveness of loyalty programs in the industry by initiating correctly designed programs that address the passengers' needs to increase patronage (Furinto et al., 2009). The hope is that the research will unearth the basis of the various loyalty schemes in place in the industry thereby understanding the direction the executives intend to take in the future to enhance the programs' appeal to the market. The qualitative research by using semi-structured in-depth interviews was deemed valuable in collecting sufficient evidence the loyalty program has in unlocking competitive advantages for bus companies. Numbered are the days of the sector operating in a silo where marketing tools for business performance enhancement are unique to the industry. Technological and financial advancement prescribes that uniformity brings about effectiveness and efficiency.

Implications and Contribution to Knowledge: While the study acknowledges the implementation of loyalty programs in road passenger transportation industry of Zimbabwe, it also indicates how there are gaps in its application which would have different characteristics produced both by internal and external intervention. The study highlighted the contextual use of loyalty schemes by the participating companies but most importantly the characteristics not in use compared to other industrial sub-sectors. Passenger transportation sub-sector has not fully comprehended the value of loyalty programs as they become obligatory in most industrial sectors (McCall \& McMahon, 2016). Globally, loyalty programs have moved from just being tools to enhance the customer-company relationship to allowing companies to view patterns of purchase in the transport industry's case of travel thereby extracting the highest possible financial value in the process. This study contributes to knowledge in the following regard.

Theoretical and Managerial Implications: Although there is a proliferation of loyalty programs in the industry, there is little being done to make this specific and valuable to the companies in the same manner airlines adopted varying programs over the past few decades. Similarly, it is my view that loyalty programs in the industry be cross-sectional to include special treatment rewards thereby enhancing benefits for passengers. There are virtually no value is derived from the current programs in place towards either developing plans to address passenger travel plans. The industry needs to adopt schemes similar to those being used in the airline industry thereby improving on the collection of passenger information for purposes of ascertaining their consumers' purchase behaviour and service requirements. However, the present study has limitations consisting firstly of the sample size which may not necessarily have produced results that allow for inference onto the populations of passenger transportation companies in the country.

Secondly, the research focused on companies providing inter-country services mainly as they have the highest possibility of generating repeat business that would make loyalty programs function efficiently. Possibly investigating companies providing inter-city and rural transport services may produce varying results, which creates room for further studies. Thirdly, though the majority of respondents (67\%) are responsible for making the decisions on what loyalty programs should be in place, the remainder of the sample does not have the influence to make such choices hence may have polarised the survey. Further studies may be necessary for a larger pool of decision-makers to assess how they value loyalty programs in their businesses. Lastly, there has not been an undertaking, especially in the road passenger transportation sub-sector to ascertain the perception of passengers towards the use of loyalty programs as a tool of relationship management, which proffers an opportunity for further study.

\section{References}

Aaker, D. A. (1992). The Value of Brand Equity, Journal of Business Strategy, 13(4), 27-32.

Awolusi, O. D. (2014). Factors influencing the internationalization of Nigerian manufacturing firms: An empirical analysis, British Journal of Business and Management Research, 1(2), 79-102.

Awolusi, O. D., Magaji, N. \& Odunlami, S. A. (2015). Impact of Leadership Style on Organizational climate in the Nigerian Insurance Industry, International Journal of Business and Industrial Marketing, 1(3), 45-52.

Basera, C. H. (2014). Maximizing Customer Retention through Loyalty Programs in Perfect Competition Markets: A Case Study of Fast Food Retail Businesses in Masvingo Urban, Zimbabwe, International Journal of Education and Research, 2(2), 1 - 12.

Beck, J. T., Chapman, K. \& Palmatier, R. W. (2015). Understanding Relationship Marketing and Loyalty Program Effectiveness in Global Markets, Journal of International Marketing, 23(3), 1 - 21. 
Bergman, M. M. \& Coxon, A. P. M. (2005). The Quality in Qualitative Methods, Forum: Qualitative Social Research, 6(2), 23-34.

Berman, B. (2006). Developing an Effective Customer Loyalty Program, California Management Review, 46(1), $123-148$.

Blazi, C. \& Awolusi, O. D. (2020). Employee Engagement in Multinational Diverse Organization in Difficult Terrain: A Study of Non-Family Station Organization, Information Management and Business Review, 12(1), 45-62.

Burnard, P. (2004). Writing a Qualitative Research Report, Nurse Education Today, 24(1), 174 - 179.

Burnard, P., Gill, P., Stewart, K., Treasure, E. \& Chadwick, B. (2008). Analysing and Presenting Qualitative Data, British Dental Journal, 204 (8), 429 - 432.

Denzin, N. K. (1989). Interpretive Interactionism, Newbury Park, CA: Sage.

Dick, A. S. \& Basu, K. (1994) 'Customer Loyalty: Towards an Integrated Conceptual Framework, Journal of the Academy of Marketing Science, 22(2), 99 - 113.

Easterby-Smith, M., Thorpe, R. \& Jackson, P. (2012). Management Research, $4^{\text {th }}$ Edition, London: SAGE Publications.

Furinto, A., Pawitra, T. \& Balqiah, T. E. (2009). Designing Competitive Loyalty Programs: How Types of Program Affect Customer Equity, Journal of Targeting, Measurement and Analysis for Marketing, 17(1), $307-319$.

Ferguson, R. \& Hlavinka, K. (2007). Quo Vadis: Sizing Up the U.S. Loyalty Marketing Industry. Milford OH: Colloquy.

Hossain, M. Z., Kibria, H. \& Farhana, S. (2017). Do Customer Loyalty Programs Really Work in Airline Business? - A Study of Air Berlin, Journal of Service Science and Management, 10(1), 360 - 375.

Jang, D. \& Mattila, A. S. (2005). An examination of restaurant loyalty programs: what kinds of rewards do customers prefer? International Journal of Contemporary Hospitality Management, 17(5), 402 - 408.

Johnson, B. \& Christensen, L. (2008) Educational Research: Quantitative, Qualitative, and Mixed Approaches (p. 34). Thousand Oaks, CA: Sage Publications.

Kang, J., Alejandro, T. B. \& Groza, M. D. (2015). Customer-company Identification and the Effectiveness of Loyalty Programs, Journal of Business Research, 68(1), $464-471$.

Lawrence, J. \& Tar, U. (2013). The use of Grounded Theory Technique as a Practical Tool for Qualitative Data Collection and Analysis, The Electronic Journal of Business Research Methods, 11(1), 29 - 40.

Lichtman, M. (2006). Qualitative Research in Education: A User's Guide (pp. 7 - 8). Thousand Oaks, CA: Sage Publications.

Liu, Y. \& Yang, R. (2009). Competing Loyalty Programs: Impact of Market Saturation, Market Share, and Category Expandability, Journal of Marketing, 73(1), 93 - 108.

Lovelock, C. \& Wirtz, J. (2007). Services Marketing: People, Technology, Strategy. Prentice-Hall, New Jersey.

Magatef, S. G. \& Tomalieh, E. F. (2015). The Impact of Customer Loyalty Programs on Customer Retention. International Journal of Business and Social Science, 6(8), 78-93.

Matira, K. M. \& Awolusi, O. D. (2020). Leaders and Managers Styles towards Employee Centricity: A Study of Hospitality Industry in United Arab Emirates, Information Management and Business Review, 12(1), 121.

McCall, M. \& McMahon, D. (2016). Customer Loyalty Program Management: What Matters to the Customer, Cornell Hospitality Quarterly, 57(1), 111 - 115.

Morgan, R. M. \& Hunt, S. D. (1994). The Commitment-Trust Theory of Relationship Marketing, Journal of Marketing, 58(3), 20 - 38.

Orb, A., Eisenhauer, L. \& Wynaden, D. (2001) Ethics in Qualitative Research. J Nurs Scholar, 33(1), 93-96.

Singh, R. \& Khan, I. (2012). An Approach to Increase Customer Retention and Loyalty in B2C World, International Journal of Scientific and Research Publications, 2(6), 23-34.

Sharp, B. \& Sharp, A. (1997). Loyalty Programs and Their Impact on Repeat-Purchase Loyalty Patterns, International Journal of Research in Marketing, 14(5), 473 - 486.

Strauss, A. L. \& Corbin, J. M. (1990) Basics of Qualitative Research, 15, Newbury Park, CA: Sage.

Tao, S., Corcoran, J. \& Mateo-Babiano, I. (2016). Modelling loyalty and behavioural change intentions of busway passengers: A case study of Brisbane, Australia, IATSS Research, 134(1), 1 - 10.

Temporal, P. (2000) Branding in Asia, John Wiley \& Sons, Singapore.

Thompson, F. M. \& Chmura, T. (2015). Loyalty Programs in Emerging and Developed Markets: The Impact of Cultural Values on Loyalty Program Choice, Journal of International Marketing, 23(3), 87-103. 
Warusznski, B. T. (2002). Ethical Issues in Qualitative Research, In Van den Hoonaard WC, Walking the Tightrope: Ethical Issues for Qualitative Researchers. University of Toronto Press, 152.

Wicks, A. \& Whiteford, G. (2006). Conceptual and Practical Issues in Qualitative Research: Reflections on a Life History Study, Scandinavian Journal of Occupational Therapy, 13 (2), 94-100.

Vilkaite-Vaitone, N. \& Papsiene, P. (2016). Influence of Customer Loyalty Program on Organizational Performance: A Case of the Airline Industry, Engineering Economics, 27(1), 109-116.

Yi, Y. \& Jeon, H. (2003). Effects of Loyalty Programs on Value Perception, Program Loyalty, and Brand Loyalty, Journal of the Academy of Marketing Science, 31(1), 229-240.

Yin, R. (2003). Case Study Research: Design and Methods, (3rd Edition Ed,). Thousand Oaks CA: Sage 